\title{
The Minority Nations of Spain and European Integration. A new framework for autonomy?
}

\author{
Michael Keating \\ University of Western Ontario \\ European University Institute
}

For Spanish Cultural Studies

February 1999

Michael Keating

Department of Political Science

University of Western Ontario

Social Science Centre

London

Canada, N6A 5C2

Tel. (1) 5196792111 ext. 5160

FAX (1) 5196613904

Email: keating@sscl.uwo.ca 


\begin{abstract}
The transformation of the state in western Europe provides new opportunities for expression for minority nations. Spain has a long history as a multinational state and, in the twentieth century, this has been one of the principal sources of political conflict. Catalan and Basque nationalists and Galician regionalists see in Europe a new arena for the expression of their national ambitions, while maintaining a degree of ambiguity about their ultimate goals and the question of sovereignty. Their strategies in Europe are rather different, reflecting the different history and character of the three territories.
\end{abstract}

\title{
Nationalism and the nation-state
}

It is commonly held in the social sciences that nationalism is a movement aimed at the establishment of a nation-state and that the nation-state is the fundamental unit of the world political order. This is the lesson of the modernist school, enunciated by Kedourie ${ }^{1}$, for whom 'nationalism is a doctrine invented in Europe at the beginning of the nineteenth century and reprised most recently by Hobsbawm ${ }^{2}$ who confines nationalism to the period c. 1780-1990. If this thesis is correct, then there was no nationalism before the rise of the modern state, and there can be no nationalism in a world in which the state has lost its sovereign authority. It is perhaps significant that this modernist thesis is most strongly held by writers with their origins in central Europe. Those with roots in the historic nationalities of western Europe, whose existence predates the rise of the modern state, see nationalism as more enduring principle, one which can change its institutional format over time and is not necessarily tied to any specific state form. ${ }^{3}$ 
The idea of the state has been with us a long time, but the nation-state, in the form in which we know it, is a rather recent phenomenon. It represents the coincidence in space of a number of principles of social and economic organization. It is the primary focus of collective identity, reinforced and transmitted through culture and socialization. This collective identity in turn provides the basis for social solidarity. The state is the framework for internal and external security. It frames an economic system, allowing us to talk of national economies, with definable, if not impermeable, boundaries. It is a set of institutions and mechanism for policy making. Where the state as an institutional form coincides with the national as a cultural or felt reality, the we can speak of the nationstate. In this sense, the nation-state is indeed the product of the modern era. ${ }^{4}$ Indeed, the association is so strong that the hyphenated expression has come to be used as a singular term in much of the social sciences. ${ }^{5}$ Yet this is only one form of state, the product either of ethnic fragmentation, as in eastern and central Europe, or of mass socialization of citizens into a shared identity, as in much of western Europe. In most European states, maintaining state unity and cohesion has involved a continuous exercise in territorial management. ${ }^{6}$ This is most obvious in multinational states like the United Kingdom and Spain, but applies elsewhere as well.

The nation-state and is currently undergoing substantial changes. It is transformed institutionally from above, by the rise of international regimes, notably the European Union (EU); and below by territorial assertion. Its functional capacity remains high, but interdependence is limiting its autonomous use of this capacity. Its capacity for economic management is being eroded from above, by globalization, capital mobility and the rise of the multinational corporation; laterally by the advance of the market; and from 
below by forms of economic restructuring rooted in local and regional specificities. The three-directional erosion of the nation-state from above, from below, and laterally in the face of the market, has broken the link between economic change and policy making and between policy making and representation. It has undermined social solidarity and made difficult the old class compromises and trade-offs which underpinned the west European welfare settlement of the postwar era. It has weakened the capacity of states to manage their spatial economies. It has even threatened economic efficiency, by militating against the production of public goods and the social cooperation which is the essential counterpart to competition in a market economy.

At the same time, a new continental regime is being built in Europe, providing a new economic and political space and framework for identities. This European political space is, compared with the nation-state, rather disorganized and complex. Some observers stress the constitution of the EU, analagous to other international organizations in which states play the dominant role. Others point to the possibilities for non-state actors to operate with a certain degree of autonomy, perhaps by-passing the state altogether and certainly operating at the margin of the state system. There has developed a considerable literature on regions and their ability to operate within Europe. ${ }^{7}$

Europe in particular provides a new context for national minorities and the management of nationality issues. It diffuses sovereignty by creating a new layer of political authority and, however much some state leaders might deny it, irreparably damages the doctrine of absolute sovereignty. This creates an opening for those challenging sovereignty from below and brings in a new set of concepts and a new political vocabulary. Europe also encourages the growth of multiple identities among both citizens and political leaders, a 
principle which can also be extended downwards. It provides a new political space, organized in a complex and asymmetrical manner, in which a variety of state and nonstate actors operate, seek expression and exert influence. Of course, the European Union continues to be dominated by states, who are represented in the Council, where final decisions are taken, but there remains a large sphere of politics around it, in which multiple influences can be brought to bear. Beyond the EU, the Council of Europe provides another political arena in which national minorities can find an audience; and through the European Convention for the Protection of Human Rights divorces the idea of universal human rates from the nation-state. In these circumstances, nationalism ceases to be a zero-sum game in which any gain by national minorities represents an equivalent loss of authority by the state and in which only one national identity can prevail over one territory. Specifically, Europe provides two things for national minorities. The first is a series of opportunities to influence policy, using the multiple channels of influence available. The second, perhaps more important, is that it creates a new symbolic realm, a discursive space in which minority nationality claims can be advanced without necessarily entering into terminal conflict with the host state.

So we are in a world where multiple spheres of authority coexist with multiple systems of action. It would be a serious error to present this as totally new, or to contrast it with a mythical state of the classical era which was able to monopolize authority and internalize the policy process. These tendencies have always been present, but have been greatly magnified in the contemporary era and affect most seriously those states which in the past have sought to centralize and monopolize authority. In another sense, these trends 
represent a step back in history, to an era of overlapping authority, multiple identity and complexity, before the rise of the modern state.

These trends affect different states in different ways. Some, like Germany and France, have proved resilient. In others, where there are pre-existing cultural fault-lines, or where the state has historically been ineffective in achieving national integration, there are renewed centrifugal tendencies, as competing conceptions of the nation and collective identity are revived as alternative ways of confronting the challenge of globalization and the disintegrative effects of the international market. Notable cases are Canada, Belgium, the United Kingdom and Spain. Here we find renewed minority nationalisms, seeking to use the new global order and, in particular, continental regimes like the European Union and NAFTA, as a framework for new forms of autonomy.

\section{Spain, the nation and Europe}

The Spanish state has historically been conspicuously unsuccessful in building a unitary nation. The first Spanish state was a federation of the kingdoms of Castile and Aragon, themselves internally differentiated. Aragon was a confederation, in which Catalonia enjoyed a large measure of self-rule. In the kingdom of Castile, the historic fueros, notably in the Basque provinces, restricted arbitrary central power. Soon after unification, Spain was diverted into imperial ventures, and under Charles V was linked to the Holy Roman Empire. This was therefore a diverse and sprawling polity, with multiple centres of authority and overlapping spheres of sovereignty. The minority nations, in Catalonia, the Basque provinces and Galicia, were as inclined to look outward as inward. Catalonia thrived in the middle ages and early modern period as a Mediterranean trading nation. 
The Basque provinces were oriented to the Atlantic and continental trade and until the early nineteenth century maintained free trade with the world, while facing customs barriers with Spain. Galicia was also an Atlantic economy, and developed close links with America. Attempts in the seventeenth century to impose a unitary state on the lines of Louis XIV's France met with limited success. In 1714 Catalonia's self-governing institutions were suppressed and in the course of the nineteenth century Basque privileges were reduced to the fiscal concession of the concierto económico, but the central state lacked the prestige, authority or instruments to create a truly unitary state on French lines. Nor did liberals and republicans in the course of the nineteenth century managed to emulate their French counterparts in constructing a unitary Spanish nation. ${ }^{8}$ Madrid remained largely in the grip of the agrarian/aristocratic/military complex unable to engage in a programme of modernization and state-building. Industrialization and social modernization were most marked at the periphery, in Catalonia and the Basque Country, where local bourgeoisies took the lead in economic development. By the turn of the century, alternative national visions had emerged in these peripheries, the Catalan one dedicated to modernization and development, the Basque one more rooted in traditionalism and the defence of traditional ways against modernity. In the twentieth century, Francoism had its turn, but its brutal repression of the minority nationalities merely served to associate centralization with fascism and to ensure an alliance between democratic forces and the representatives of the periphery, even the conservatives.

The national minorities question has been one of the main preoccupations of twentieth century Spanish politics and during the transition to democracy it was recognized that this issue must be dealt with. At the same time, Europe was seen as an external support 
system for the emerging democracy, a force for democratic stability, economic growth and social modernization. In the minority nations, Europe took on a particular importance as a new framework in which their aspirations to self-government could be realized, without taking on the Spanish state head-on, a strategy which had led to such tragic results in the past. So Europe has become a key theme for Catalan and Basque moderate nationalism. Both Convergència i Unió (CiU) and the Partido Nacionalista Vasco (PNV) are strongly pro-Europe while maintaining a studied ambivalence about their ultimate constitutional aspirations. The European Union, with its diluted and shared sovereignty and complex institutional arrangements, provides the ideal counterpoint to this, enabling them to engage in complicated strategies and manoeuvres. More concretely, Europe is seen as a source of economic opportunities; as source of support for their cultural and linguistic promotion policies in the context of a hostile Spanish state; and as a source of support for their self-government aspirations, with its commitment to subsidiarity and the Europe of the Regions concept, and through the possibilities of alliances with other minority nations and regions. Europe is thus used as a resource for nation-building, but not necessarily for state-building in the classic sense. Of course, this project is always contentious, since the form and content of nationalism are matters of political debate. In particular, there are complaints that the dominant nationalist parties have sought to monopolize nationalism in the interest of maintaining their own power and social networks. This problem may be exacerbated within Europe, since in order to operate there, it is necessary to determine what the interest of the minority nation is and who speaks for it. Europe may thus be another forum within which competing conceptions of nationalism are fought out. 
Catalonia, the Basque Country and Galicia have never been nation-states in the modern sense, the theory of absolute sovereignty (which many consider a Spanish import from France) has never taken root there, and most nationalists are aware of the real limitations of sovereignty in a modern, complex and interdependent world. On the other hand, they are able to draw on their own historic traditions of shared sovereignty, complex authority and multiple spheres of government to forge and sustain strategies for maximizing their opportunities in the new Europe. While Catalans, Basques and Gallegos are all engaged in this exercise, however, there are differences in their orientations and strategies, reflecting the different characteristics and aspirations of the three movements.

\section{Catalonia and Europe}

Catalan nationalism has, since the early part of the twentieth century, presented itself as modernizing and European. Europe was seen as a symbol of modernity, an important counterpoint to the reactionary forces in Madrid. Yet at the same time, the Catalan bourgeoisie who led the first 'regionalist' and then nationalist movements were fiercely protectionist since, while Catalan industry was the most competitive in Spain, it could not compete with British, German and northern Italian products. So Catalan industrialists, while pressing for home rule, needed the Spanish state to deliver tariff protection and a captive market - they also needed to call on the forces of the state to keep their own revolutionary proletariat in order. Politically, too, they looked both ways, alternating between seeking local autonomy and gaining power within the state with a view to 'catalanizing' Spain. The bourgeois nationalist movement's failure to resolve these contradictions was an important element in its decline from the 1920s. Thereafter 
leadership passed to the radical lower middle class and elements of the left, committed to a more progressive social programme and a stronger form of nationalism.

After the Second World War, the revived Catalan movement in clandestinity reemphasized the European theme in the context of the European unity project.

Connections with European politicians through the Socialist and Christian Democratic internationals were important here, as was the experience of exile in France and elsewhere. Protectionism, now associated with Francoist autarky (up until the 1960s) was abandoned in favour of free trade and the nationalist project was given a strongly proEuropean tinge. The restored Generalitat took a strongly pro-European stance and, even in advance of Spanish accession to the European Community, established a presence in Brussels via the Patronat Català Pro Europa, a public-private agency to represent Catalan interests in the EC. Jordi Pujol was an early exponent of the Europe of the Region concept ${ }^{9}$, seeing it as a framework for a revived but not separatist catalanism. For the last twenty years, he has been one of the leaders of this movement, losing no opportunity to press the cause of regionalism within the European Union. Europe of the Regions is an ambivalent concept, covering a variety of positions, from support for stronger regional policy measures within the EU, through demands for better representation of regions in Brussels, to recognition of the regions as a third level of government. It stops short, however, of the policy of independence in Europe espoused by the Scottish National Party, as Pujol, when pressed, has made clear. Pujol's concept of Europe of the Regions gives a special place to regions with their own culture or autonomous institutions, which regionalists wish to distinguish clearly from mere administrative regions or local governments, and has much in common with the Europe 
of the Cultures concept pressed by the government of Flanders, which seeks a special case for cultural regions (or what we might call minority nations). At the same time, the Catalan government loses no opportunity to present itself in other international arenas, notably the Mediterranean, central Europe, and Latin America. The end point is, as always, ambiguous, but might be summed up as a return to Catalonia's pre-1714 status as a self-governing trading nation in a federal or confederal relationship with Spain, but operating freely in other arenas.

The Esquerra Republicana de Catalunya takes a more radical stance, supporting Catalan independence, but this is a long-term aspiration linked to changes in Europe. Their vision is of a Europe of the Peoples, in which the existing states fade away and small nations and regions take their place. Matters such as defence or currency would be handled by a European government, while other matters would be dealt with locally. This strictly utopian vision is accompanied by attacks on CiU for its monopolization of Catalanism and a constant pressure for more power for Catalonia within Spain.

This link between minority nationalist assertion and support for Europe is found widely in other member states. In Catalonia the politics of multiple identity builds on the preexisting sense of dual Catalan and Spanish identity. Surveys have repeatedly shown that most Catalans do not see a fundamental incompatibility between being Catalan and being Spanish. ${ }^{10}$ Building the link to Europe has taken a little time. According to the European Values Study of 1990, Catalans, while broadly in favour of Europe, were somewhat less enthusiastic than people in other parts of Spain ${ }^{11}$ apparently viewing Europe more as a neutral political space less hostile to their aspirations than positively as a new form of identity. On the other hand, evidence from the mid 1990s shows Catalans becoming more 
European. Catalans in the majority continue to feel both Spanish and Catalan but the European identity is ever more salient and, among native Catalans, is now equal to Spanish identity. ${ }^{12}$ Convergència $i$ Unió is in favour of the most advanced programme for European integration, including the single currency and common foreign and security policies, but accompanies this with demands for the strict application of subsidiarity and a guaranteed role for regional interests. ${ }^{13}$

The present constitution of the European Union falls considerably short of CiU's demands, but they have been very active making the most of existing opportunities. Catalonia continues to be represented in Brussels by the Patronat Català Pro Europa which, while closely linked with the government in office, is still a public-private consortium. Significantly, the Generalitat has not taken advantage of the Constitutional Court ruling allowing autonomous communities to open their own offices in Brussels, but has deliberately maintained a broad-based institution, in line with Pujol's philosophy that Catalonia does not have a foreign policy, but rather an external presence. The Brussels office is used for information purposes and as a channel for Catalan interests to lobby the Commission, but not as a rival to the Spanish delegation. Indeed it co-operates rather closely with the Spanish permanent representation. Catalonia has been very active in the Assembly of European Regions and pressed hard for the establishment of the Committee of the Regions, finally set up under the Maastricht Treaty. In the preparations for the Amsterdam Treaty of 1997, it supported a stronger Committee of the Regions, with recourse to the European Court and the removal of municipal representatives who, the stronger regions think, dilute the committee. It also pressed for the operationalization of the principle of subsidiarity, to be enforced by the European Court. None of these 
demands was successful. Much use has been made of the European Parliament; a great deal of political mileage was gained from a resolution of the Parliament recognizing Catalan as a language of the Community, though the practical effect of this is rather small.

Catalonia has been heavily involved in inter-regional networking, forging links with regions across Europe. These contacts serve economic, political and cultural purposes, helping to establish Catalonia as a transnational actor. The most celebrated link is through the Four Motors of Europe, a consortium of regions each of which is the most advanced technically in its own state. Certainly, Catalonia stands out within Spain in this respect, but it is considerably behind its partners in Rhône-Alpes, Baden-Württemberg and Lombardy. Nonetheless, the partnership serves an important role in raising the prestige of Catalonia and in allying it with the more dynamic and powerful regions of Europe.

Catalan strategy in Europe involves a series of small initiatives rather than dramatic demands. It is opportunistic, looking for openings wherever they occur and seeking gradually to broaden the scope for regional interests and minority nations. The strategy, in alliance with other European regions, has had some success and regions now feature as actors in European politics to an extent unthought of a few years ago. Yet there has not been a fundamental shift of power from the states to the regions, as the strategy would require, and $\mathrm{CiU}$ has continued to stress the need to operate within the Spanish state. This pragmatic strategy accompanies and expansive discourse in which Europe is presented as the ideal outlet for national aspirations. Europe has certainly given more credibility to the idea of stateless nation building. Yet there remains a gap between this ambitious discourse and the limited concrete opportunities available. Younger nationalists show 
evidence of impatience with the gradualist and incremental strategy of Pujol and its limited concrete results. At the same time, the move to economic and monetary union, with the single currency, with dramatically reduce the importance of the state economic framework. In that case, the policy of independence within the EU may make more headway.

\section{The Basque Country in Europe}

The origins of Basque nationalism are very different from those of its Catalan counterpart ${ }^{14}$ and while there has been considerable convergence over recent decades, significant differences in attitudes and assumptions remain. Early Basque nationalism was rooted in local particularism and insularity, with a racist element rejecting outsiders of all sorts but especially Spaniards (among whom were included Catalans). It was antiindustrial and politically conservative, if not reactionary. While these features were modified considerably in the early twentieth century with the accession of a section of the Basque bourgeoisie, the element of particularism has remained. Basque industrialization really took off only when the prohibition on the export of iron ore brought in capital to Vizcaya, which provided the basis for its iron and steel industries. Basque industrialists had extensive overseas connections, notably with England (even now Basque nationalists almost invariably, if bizzarely, insist on referring to the whole United Kingdom as England). The autonomous Basque government under the Second Republic actively sought support and contacts abroad, and sustained these vigorously in the years of exile. ${ }^{15}$ The Basque Nationalist Party (PNV) was converted to the cause of European integration by its contacts in the Christian Democratic International and by 1949 had modified its 
independence policy to call for national autonomy within a federal Europe (PNV, 1995). ${ }^{16}$ The autonomous government has, since its establishment, played the European card very strongly. Yet there are differences with the Catalan case. Basque nationalism has a stronger separatist element and while the PNV is as ambivalent as CiU on its ultimate aspirations, these do point more clearly to an independent Basque state. The PNV did not accept the Spanish Constitution of 1978, since it was presented as the work of a sovereign Spanish state and does not respect the Basque fueros as inherent rights. The final goal of most of the PNV is clearly national independence within the EU, although this is expressed as a long term aspiration rather an immediate aim. There is a marked contrast to the rhetoric of $\mathrm{CiU}$, which carefully places Catalonia within the context of Europe and of Spain and explicitly renounces separatist aims.

Basque nationalism is also much more divided than its Catalan counterpart, with a radical wing committed to total independence for all seven Basque provinces, including Navarre and the provinces in France. This makes it much more difficult to project a Basque interest or project, while the persistence of violence creates a serious image problem. The irredentist demand, which questions existing state borders, is not compatible with the existing forms of European unity, which are predicated on the respect of frontiers, an essential precondition for policies such as cross-border cooperation that seek to reduce their functional importance. In any case, radical Basque nationalism rejects the present European Union, calling for a people's Europe through the destruction of existing states.

Basques feel both markedly less Spanish and less European than Catalans. In the 1994 survey, the mean score for Spanish identification in the Basque Country was 5.71, against 
8.26 in Catalonia and 8.8 for Spain as a whole. Basque identification with Europe scored 5.2 against 7.48 in Catalonia and 6.8 for Spain as a whole. ${ }^{17}$ The picture is similar for the stereotypes that the various national groups sustain. Basques have the poorest image both of Spaniards and of Europeans of all the autonomous communities, with mean scores of 6.13 and 5.41 respectively, against 8.41 and 6.94 for Spain as a whole. Catalans come immediately after Basques and Navarrese in their negative views of Spaniards, with a mean score of 7.64. On the other hand, they have the second most favourable view of Europeans, after Valencians, at 7.36, above the Spanish average of $6.94 .^{18}$ So, in line with their historic traditions, the Basques remain particularistic and have more difficulty than the Catalans (or the Scots or Flemish) in living with multiple identities, an essential prerequisite for playing the new European politics.

The PNV, on the other hand, is a supporter of the EU and favours all measures of integration, including the single currency. Like the CiU it has played the Europe of the Regions game, but with more radical objectives in mind. In 1995, they came out with a set of radical proposals involving direct Basque representation in European institutions, a strategy difficult to reconcile with the existing constitution of the EU. More recently, they have been pressing for the extension to Spain of article 146 of the Maastricht Treaty, which allows ministers of substate governments to represent the state in the Council of Ministers. CiU has been more reticent about this option, reasoning that it would require a constitutional amendment; an underlying concern is that use of article 146 would require agreement among all the autonomous communities on a joint position, which would undermine the distinctiveness of Catalonia. The Basque position is more particularist, 
envisaging representation by one or a small group of autonomous communities in matters where they had a common interest.

In line with its quasi-statist ambitions, the Basque government took advantage of the Constitutional Court ruling to establish its own government office in Brussels. This represents a more politicized form of representation and direct lobbying than that available to Catalonia. The Basque Country is also more dependent than Catalonia on moneys from the EU Structural Funds, and maintains strong links with Brussels in the planning and management of these although, as elsewhere, the money still has to pass through Madrid. The Basques are strong supporters of the Committee of the Regions and have taken an active part there and in other pan-European ventures, although they have not provided the leading role which the Catalans have. Like Catalonia, the Basque Country is involved in a series of inter-regional consortia, notably the Conference of Peripheral Maritime Regions and its Atlantic Arc subsidiary. It has also been involved in a series of cross-border initiatives with Aquitaine, bringing together Basques on both sides of the Pyrenees, although the continuing violence aimed at abolishing the border has had the perverse effect of making this type of co-operation more difficult.

The symbolic discourse of Europeanism has less resonance in the Basque Country than in Catalonia, since there is a weaker historic basis for it. Unlike Catalonia, the Basque Country has not historically been a land of passage between Europe and the rest of Spain and nationalism has a more isolationist bent. The Europe of the Regions discourse in Catalonia is seen as an end in itself but, while the Basques are willing to play this game, they are clear that it is a mere way station towards national self-determination. 


\section{Galicia in Europe}

Nationalism has long been weaker in Galicia than in the other historic nationalities. Its political culture remains conservative and clientelistic, dependent on connections with the central power in Madrid. Nationalism has historically been fragmented and, while the Bloque Nacionalista Galego is the opposition in the Galician parliament, it is a heterogeneous coalition including radical nationalists, home rulers, social democrats and Marxists. Its rhetoric tends to be demagogic and anti-European, focusing on the adverse effects of European policies on key sectors such as fisheries, milk and ship-building and without the positive engagement with Europe that has characterized minority nationalists in other parts of the EU. The absence of a bourgeois regionalist/nationalist party is a major contrast with Catalonia and the Basque Country, although there was an attempt at such a party in the 1980s in the form of Coalición Galega. The ruling party is a branch of the Spanish Partido Popular, (PP) dominated since the late 1980s by Manuel Fraga. The PP in turn has two sectors, one linked to Madrid and neo-liberal in orientation, the other entrenched at the provincial level and rooted in traditionalist values and clientelistic networks. The two are held together largely by the personality of Fraga. It is Fraga, too, who has been largely responsible for introducing the European regionalist theme to Galicia. Fraga's regionalism is to be distinguished sharply from nationalism, being informed by a strong sense of Spanishness and repeated insistence that Galicia is an integral part of Spain. Within these limits, Fraga has ardently pursued the idea of a Europe of the Regions, espousing the idea of three levels of government, subsidiarity and the need for a Galician presence in Brussels. He himself is an indefatigable traveller, voyaging constantly in Europe and Latin America to project the image of Galicia (and of 
himself as an international statesman). Galicia is a large recipient of European Structural Funds moneys and this creates a strong interest in European policy as well as strengthening Fraga's support for European regionalism.

Gallegos have a rather strong sense of regional identity but most of them think of this as compatible with Spanish identity. ${ }^{19}$ They rate slightly below the average in their positive attitudes towards Spaniards and Europeans and feel slightly less Spanish and slightly more European than the average.$^{20}$ This presents a much less dramatic picture than either Catalonia, with its turning to Europe and multiple identity, or the Basque Country, with its continued particularism.

The European dimension in Gallego identity does appear to be getting stronger. It is likely that in the longer term Europe will serve to undermine the dependent political system and clientelistic practices of Galicia, widely blamed for its economic backwardness. Regional policy has been largely Europeanized and Brussels is bringing pressure to bear to spend less on infrastructure projects, which can be used for political patronage, and more of business development, innovation and human capital. The old political system is rooted in the small towns and rural areas, a declining part of the region, and is weaker in the cities and the coastal areas, which are reaching out to Europe. The new Euro-Region, linking Galicia to the north of Portugal, provides economic linkages and resources independent of the central state and encourages more independent forms of development. What is still lacking, however, is a moderate nationalist or regionalist coalition able to take advantage of these trends and create a vision for Galicia in Europe comparable to that promoted in Catalonia. 


\section{Nations beyond the state?}

European integration has transformed the old nationalities question in Spain. The tension between the españolista insistence on the unity and uniformity of the state was always incompatible with the national realities of Catalonia, the Basque Country and Galicia. The Estado de las autonomías, together with European unity and federalism, present a new framework, imposing the idea of limited sovereignty, territorial accommodation and subsidiarity. This permits the projection of the nation and its cultural and economic interests, without raising the dangerous issue of separatism. A new discourse of stateless nationhood and shared sovereignty is legitimated both by the historic traditions of Spain's minority nations, and by the European project itself. Europe provides allies and resources in the fight against centralizing tendencies within the Spanish state. This has all served to normalize territorial politics, keeping it largely within political and constitutional limits and taming separatist tendencies. It has not, on the other hand, dealt with the issue of radical Basque nationalism. The EU is based on the stable formations of the existing states, however much these may be losing real power and authority.

It has often been remarked that Spain is a laboratory for territorial politics, since it contains such diverse regions with such contrasting experiences. In approaching the issue of Europe, we can discern three distinct models in the three historic nationalities. The Catalan strategy, based on diffused sovereignty and drawing on Catalan traditions of limited sovereignty, asserts Catalan identity strongly while placing this within the context of the new, complex networks of power. Its resolutely non-separatist thrust is intended, albeit not always with success, to disarm Spanish elites who might see Catalonia as a threat to the integrity of the state. ${ }^{21}$ It uses Europe as a discursive space within which the 
Catalan nation can be projected and a mirror from which it can be reflected, while seeking every opportunity to exert influence and extract resources from European institutions. The end point of constitutional evolution is never defined except to indicate that it involves greater Catalan autonomy, the recognition of the plurinationality of Spain and a bigger place for regions and stateless nations in Europe. It tends to be prudent and conciliatory, avoiding confronting the Spanish state or its opponents head on. The Basque strategy is, at one level, similarly opportunistic, looking out for possibilities wherever they occur. Yet the overall drive is more clearly separatist, rejecting the Spanish framework, at least in the long term and seeking a separate presence within a reordered Europe. While this affords plenty of scope for cooperation with the Spanish government on individual policy issues, it does not permit a common vision of Spain since the symbolic references are quite opposed. The Galician model is different again. There is no shared or even dominant vision of Galicia in Europe. The nationalists for the most part remain suspicious, adopting an oppositional attitude. Fraga has a very positive attitude but, in contrast to the Catalan and, a fortiori, the Basque case, this lacks the symbolic content of nationalism or a radical plan for the transformation of the state. Rather his vision fits in with the Third Level strategy associated with the German Länder, in which regions will have a defined place in European policy making but as part of their host states.

In 1998, nationalists in all three territories staged a series of meetings, with Declaration of Barcelona, followed by those of Santiago and Vittoria, seeking a common strategy in Spain and in Europe. These demanded a new, plurinational and confederal state, and made great play with the European issue. They demanded recognition by Europe of their 
national reality and of their languages and sought greater participation in the institutions of the EU. Specifically, they demanded a place in the Spanish permanent representation to the EU and its delegation in the Council of Ministers where matters affecting their competences were at stake as well as membership of Commission working parties. They demanded similar representation in other European and international bodies. They called for a more socially oriented Europe and for the application of the principle of subsidiarity. Much of this is common to the Europe of the Regions movement, but what is specific about the three Spanish minority nations is their insistence that they should have a special place, not being relegated to the status of mere autonomous communities. The apparent common strategy also masks differences in long term aspirations and in visions of Europe. While the Catalan $\mathrm{CiU}$ would no doubt be content with the Barcelona programme, with its recognition of the Spanish dimension, albeit in a new plurinational state, the PNV still hankers after full independence and participation in Europe as a state, while the BNG is divided on the issue as on other issues. It may be that the Barcelona process will lead to a new synthesis, with the Basques moderating their separatism and the BNG moving politically to the centre but this process has only begun.

There is as yet no clear institutional framework for stateless nations within Europe, for all the efforts of the Basques, Catalans and Flemish to establish one. Symbolic opportunities for national projection are legion and these may play an important role both in consolidating nation-building and in satisfying the demands it raises. Some funds are available in Europe, and there are some opportunities to influence policy, but all this is ad hoc and piecemeal. Efforts to institutionalize a 'third level' of European politics, which looked promising at the time of the Maastricht Treaty, have not been followed through in 
subsequent treaty revisions. Above all, the state remains the crucial channel of access to Europe. It is not surprising, then, that one of the priorities in the negotiations between the CiU and (especially) the PNV and the incoming conservative Partido Popular national government in 1996 was greater influence in the formation of Spanish policy within the EU. This includes provision for consultation and for substate representation in the Spanish permanent representation in Brussels and in working parties.

Nationality politics in Spain remains inherently unstable. There is a constant tendency to outbidding by the minority nationalist parties, combined with efforts in Madrid to undo whatever concessions are made. Europe merely adds to this complexity. It helps to accommodate nationalism by obscuring issues of sovereignty and avoiding absolutes. Yet by the same token it provides no end point for constitutional evolution. It is likely, therefore, that nationalist advance in Spain will proceed in step with European integration. Each advance in integration will make the state less relevant and the European arena more so, leading the nationalities to change their focus. A single currency, taking one of the very symbols of national sovereignty out of the hands of the state and shifting power massively to Frankfurt, could be the signal for a further assertion by the nationalities. Once again, we are reminded that the 'nation-state' is merely one form of political order, constantly in transition. Nations, whose connection with the state is more contingent than necessary, are also in flux, being invented and reinvented in different epochs. If Europe does evolve into a more fluid political order resembling, at least in some respects, the pre-state order of multiple and complex authority, it will be those who cling most stubbornly to the nineteenth-century form of the sovereign nationstate in places such as France, Spain and England (sic) who will find the greatest 
problems adaptation. The national minorities of Spain are offer merely a glimpse of the possible future.

1. E. Kedourie, Nationalism (London: Hutchinson 1960).

2. E. Hobsbawm, Nations and nationalism since 1780 (Cambridge: Cambridge University Press, 1990).

3. M. Folch-Serra, 'The everyday aspects of nationalism in Catalonia', International Journal of

Comparative Race and Ethnic Studies, 2.2, pp.35-45 (1995). M. Keating, Nations against the state. The new nationalism in Quebec, Catalonia and Scotland (London: Macmillan). Josep R. Llobera, The God of Modernity. The Development of Nationalism in Western Europe (Oxford: Berg, 1994).

4. It is not the product of the Peace of Westphalia (1648) pace most international relations scholars. This is true even on the external plane. The only European state which has the same boundaries in 1996 as in 1648 is Portugal, and that has lost an empire which profoundly shaped its internal politics. If we look at the internal construction of the nation state, this is even more the case. The substantive content of the nation state is the product of nineteenth century nation building.

5. So strong is the association in France that the expression nation-state has no translation in the French language. The Québécois translator of my book Nations against the State used nation and état indifferently to translate state and nation and, while I was able to correct this at manuscript stage, the publisher still inisted that the title, being oxymoronic in French, be changed to Les défis du nationalisme moderne.

6. M. Keating, State and Regional Nationalism. Territorial Politics and the European State (London: Harvester-Wheatsheaf, 1988).

7. S. Petschen, La Europa de las regiones (Barcelona: Generalitat de Catalunya, 1993); B. Jones and M. Keating (eds), The European Union and the Regions (Oxford: Oxford University Press, 1995); U. Bullman (ed.) Die Politik der Dritten Ebene (Baden-Baden: Nomos, 1994).

8. José Alvarez Junco, 'The Nation-Building Process in Nineteenth-Century Spain', in Clare Mar-Molinero and Angel Smith (eds), Nationalism and the Nation in the Iberian Peninsula (Oxford: Berg, 1996). 9. J. Pujol, Una política per Catalunya (Barcelona: Nova Terra, 1976). 
10. Félix Moral, 'Identidad regional y nacionalismo en el Estado de las autonomías, Opiniones y Actitudes, 18 (Madrid: Centro de Investigaciones Sociológicas, 1998). Manuel García Ferrando, Eduardo LópezAranguren and Miguel Beltrán, La conciencia nacional y regional en la España de las autonomías (Madrid: Centro de Investigaciones Sociológicas, 1994).

11. F. Andés Orizo and A. Sánchez Fernández, El sistema de valors dels catalans. Catalunya dins l'enquesta europea de valors dels anys 90 (Barcelona: Institut Català d'Estudis Mediterranis, 1991).

12. José Luis Sangrador García, 'Identidades , actitudes y estereotipos en la España de las Autonomías', Opiniones y Actitudes, 10 (Madrid: Centro de Investigaciones Sociológicas, 1996).

13. Convergència I Unió, Amb força a Europa. Programa Electoral, Eleccions al Parlament Europeu, 1994.

14. D. Conversi, The Basques, the Catalans and Spain (London: Hurst, 1997).

15. A. Ugalde, La Acción Exterior del Nacionalismo Vasco (1890-1939): Historia, Pensamiento y

Relaciones Internacionales (Bilbao: Instituto Vasco de Administración Pública, 1996).

16. Partido Nacionalista Vasco, Ponencias aprobadas en la Asemblea General celebrada los días 2 y 3 de Diciembre de 1995.

17. José Luis Sangrador García, 'Identidades , actitudes y estereotipos en la España de las Autonomías', Opiniones y Actitudes, 10 (Madrid: Centro de Investigaciones Sociológicas, 1996).

18. Ibid.

19. Félix Moral, 'Identidad regional y nacionalismo en el Estado de las autonomías, Opiniones y Actitudes, 18 (Madrid: Centro de Investigaciones Sociológicas, 1998). Manuel García Ferrando, Eduardo López-

Aranguren and Miguel Beltrán, La conciencia nacional y regional en la España de las autonomías (Madrid:

Centro de Investigaciones Sociológicas, 1994).

20. José Luis Sangrador García, 'Identidades , actitudes y estereotipos en la España de las Autonomías', Opiniones y Actitudes, 10 (Madrid: Centro de Investigaciones Sociológicas, 1996).

21. Pau Puig i Scotoni, Pensar els camins a la sobirania (Barcelona: Mediterrànea, 1998). 